\title{
KESETIAAN BERBAHASA INDONESIA DIPERTANYAKAN DI ERA GLOBALISASI
}

\author{
Marsudi, Siti Zahrok
}

\begin{abstract}
ABSTRAK
Era globalisasi merupakan tantangan bagi bangsa Indonesia untuk mempertahankan jati diri di pusaran pergaulan antarbangsa yang sangat kompleks. Salah satu hal yang perlu diperha-tikan adalah masalah kesetiaan pemakaian bahasa Indonesia oleh masyarakat. Misalnya, adanya anggapan bahwa bahasa asing lebih modern dan bergengsi sosial yang lebih tinggi. Kesetiaan pemakai bahasa Indonesia terhadap bahasanya telah sampai pada taraf mengkhawatirkan. Banyak masyarakat pemakai bahasa Indonesia tidak sadar bahkan tidak mengetahui jika bahasa yang dipakai atau ditulis adalah salah. Bahkan, banyak masyarakat berpendapat bahwa penyimpangan berbahasa Indonesia yang digunakan adalah bahasa yang benar. Hal ini disebabkan bahasa yang salah tersebut sudah menjadi kebiasaan masyarakat dalam kesehariannya. Dengan kondisi seperti di atas, kesetiaan berbahasa Indonesia harus disosialisasikan, bahkan perlu diadakan gerakan politik bahasa secara nasional. Misalnya, peraturan dan perundang-undangan yang telah diundangkan perlu diikuti sanksi tegas jika terjadi pelanggaran berbahasa Indonesia. Sikap setia dan bahkan bangga berbahasa Indonesia terungkap melalui kesadaran bahwa bahasa Indonesia pun mampu mengungkapkan konsep yang rumit secara cermat dan dapat mengungkapkan isi hati yang sehalus-halusnya. Dengan cara seperti tersebut diharapkan mampu menekan pelanggaran pemakaian bahasa Indonesia.
\end{abstract}

Kata kunci: Bahasa Indonesia, Kesetiaan Berbahasa, Bahasa Asing, Era Global

Presiden Joko Widodo pernah mengatakan bahwa Sumpah Pemuda merupakan buah dari dialektika, yakni untuk mencapai kemerdekaan itu yang pertama-tama harus dilakukan adalah Persatuan. Persatuan adalah gagasan dasar yang mampu melahirkan kemerdekaan Indonesia pada tahun 1945. Konsepsi persatuan inilah yang menjadikan negara kuat dan landasan dari persatuan adalah kesamaan mimpi, kesamaan cita-cita dan bersatu dalam tindakan. Berikunya,Presiden menegaskan bahwa semangat mencintai Tanah Air dengan seluruh jiwa, dan menjunjung Bahasa Indonesia sebagai buah dari rasa persatuan.

Pertanyaan yang patut dimunculkan adalah apakah bangsa Indonesia sebagai pemilik bahasa sudah menghormati bahasa sendiri? Apakah pemilik bahasa ini bangga menggunakan bahasa Indonesia? Bahkan, pada umumnya, orang tua, kita justru lebih bangga kalau anak-anak kita cas cis cus menggunakan bahasa Inggris daripada Indonesia karena dipandang lebih hebat. Akibatnya, kesan yang terjadi adaah bahasa Indonesia menjadi terpinggirkan di negeri sendiri. Hal ini dapat kita 
simak misalnya bahasa yang digunakan para pejabat pemerintahan lebih suka dan bangga menggunakan bahasa campuran Indonesia-Inggris untuk menyampaikan pendapatnya sehingga pengajaran, pembinaan, pengembangan bahasa Indonesia sangat tidak berpengaruh penggunaan bahasa yang sesuai dengan kaidah-kaidah bahasa Indonesia.

Sebagai bangsa yang besar, bangsa Indonesia sudah sepantasnya menggunakan bahasa Indonesia dan menyadari betapa pentingnya kita berbahasa Indonesia. Di berbagai jenjang pendidikan diajarkan betapa pentingnya pelajaran itu. Siswa dan mahasiswa belajar tidak hanya untuk mendapatkan dan meningkatkan nilai pada saat menerima rapor kenaikan kelas atau kelulusan, tetapi belajar karena semua pengetahuan yang diperoleh sekarang ini dari semua pelajaran sangat berguna untuk kehidupan di masa depan. Banyak orang meremehkan bahasa Indonesia, tetapi harus disadari bahwa justru salah satu sikap patriotisme yang bisa ditunjukkan kepada bangsa Indonesia adalah berbahasa Indonesia.

Seperti telah dicantumkan dalam tujuan pengajaran bahasa Indonesia pada semua jenjang pendidikan adalah membimbing anak didik agar mampu memfungsikan bahasa dalam komunikasi dengan segala aspek. Dalam pengertian ini jelas bahwa tujuan pengajaran bahasa Indonesia itu diarahkan kepada kemampuan anak didik agar melakukan komunikasi dengan bahasa Indonesia sesuai dengan fungsinya.

Selaras dengan tujuan pengajaran bahasa Indonesia maka hasil yang diharapkan setelah selesai setudi jika menjadi pemimpin yang hebat di masa depan tetap berpegang teguh dan setia terhadap bahasa nasionalnya. Bagaimana kita bisa menjadi seorang pemimpin Indonesia yang kuat apabila pemimpinnya sendiri tidak bisa berbahasa Indonesia dengan baik dan benar. Jika hal ini terjadi sangat memalukan bangsa dan negaranya. Bahasa Indonesia yang indah itu dirusak oleh bangsa sendiri, seperti bahasa campuran Indonglish dan kita menjadi bangsa yang gagap terhadap bahasa sendiri. Oleh sebab itu, bangsa Indonesia, terutama para pemimpin di berbagai lapisan, berbahasa Indonesia dengan baik dan benar merupakan salah satu keharusan baginya. 


\section{Perilaku Berbahasa Indonesia di Era Global}

Kesetiaan berbahasa Indonesia dapat diamati antara lain melalui perilaku berbahasa atau perilaku berbahasa. Sebagaimana perilaku itu dan sikap pada umumnya, perilaku berbahasa atau perilaku tutur seseorang atau sekelompok orang tidak selalu merupakan cerminan sikap bahasa. Demikian pula sebaliknya, sikap bahasa tidak selamanya tercermin dalam perilaku berbahasa Indonesia. Hanya permasalahannya terjadi inteferensi yang tidak mendukung perkembangan bahasa Indonesia. Dalam hal ini, Chaer dan Agustina (1995: 168) mengemukakan bahwa interferensi adalah peristiwa penyimpangan norma dari salah satu bahasa atau lebih. Penyebab interferensi ini disebabkan beberapa faktor, seperti dikemukakan oleh Setyawati (2010:10), yakni tiga faktor penyebab seseorang salah dalam berbahasa, antara lain sebagai berikut:

1. Terpengaruh bahasa yang lebih dahulu dikuasainya. Ini dapat berarti bahwa kesalahan berbahasa disebabkan oleh interferensi bahasa ibu atau bahasa pertama (B1) terhadap bahasa kedua (B2) yang sedang dipelajari si pembelajar (siswa).

2. Kekurangpahaman pemakai bahasa terhadap bahasa yang dipakainya.

3. Pengajaran bahasa yang kurang tepat atau kurang sempurna.

Perlu diketahui bahwa perilaku yang ditampilkan seseorang atau masyarakat tidak selalu timbul karena sikapnya, tetapi bisa muncul karena kebiasaan dan norma sosial. Perilaku membantu meringankan penderitaan orang lain seperti dicontohkan di atas bisa juga muncul karena kebiasaan, tabiat dasar manusia yang peduli dan suka menolong. Hal ini juga bisa muncul karena adanya norma masyarakat, misalnya rasa kebersamaan dan rasa sepenanggungan, rasa persaudaraan, serta rasa sebangsa dan setanah air. Perilaku menjaga, mempertahankan, dan mengembangkan bahasa daerah dan bahasa Indonesia dapat tumbuh karena kita memiliki sikap positif atau bisa juga karena adanya 'norma sosial' yaitu bahwa bahasa adalah identitas dan jati diri bangsa, seperti dinyatakan dalam ungkapan 'bahasa menunjukkan bangsa', atau karena faktor kebiasaan yang kita tumbuh kembangkan terus: kebiasaan menjaga, mengembangkan, dan membina bahasa daerah dan bahasa Indonesia. Para ahli sepakat bahwa 'kebiasaan' merupakan faktor yang paling kuat dan paling 
dominan membentuk perilaku, sedangkan 'sikap' merupakan faktor yang paling lemah dan kurang dominan. Ini berarti perilaku yang ditampilkan seseorang atau oleh suatu masyarakat tidak selalu mencerminkan sikap seseorang atau masyarakat tersebut.

Perilaku berbahasa Indonesia yang didasari kebiasaan tanpa pertimbangan baik-buruk dan benar-salahnya akan berakibat kerancuan dalam berbahasa. Kerancuan ini bisa terjadi diberbagai aspek kebahasaan, seperti bentuk kata, pilihan kata, maupun struktur kalimat. Perilaku berbahasa bangsa Indonesia saat ini sangat dipengaruhi oleh kondisi global. Berarti, keberadaan bahasa Indonesia di era global tidak akan lepas dengan zamannya, yakni era globalisasi. Bahasa Indonesia di era saat ini suka tidak suka pasti terkena pengaruhnya. Setiap pengaruh tentu akan menghasilkan suatu hal yang positif maupun negatif. Pengaruh positif bahasa Inggris terhadap bahasa Indonesia, yakni menambah khasanah perbendaharaan bahasa Indonesia dengan adanya kata serapan. Bahasa dapat berkembang karena adanya kontak dengan bahasa dan budaya lain sehingga perkembangan teknologi dan ilmu pengetahuan dapat diikutinya (Alwi, 2000:24). Dengan cara seperti ini, bahasa Indonesia bisa semakin berkembang karena adanya tuntutan zaman seperti era global ini. Kata serapan ini merupakan kata dalam bahasa asing yang telah diIndonesia-kan yang sesuai dengan kaidah. Contoh kata serapan seperti standardization (bahasa Inggris) diserap menjadi 'standardisasi' (bahasa Indonesia), organization diserap menjadi 'organisasi', computer diserap menjadi 'komputer', dan sebagainya. Dengan dampak positif ini, bahasa dan bangsa Indonesia dapat mengikuti perkembangan politik, ekonomi, ilmu pengetahuan, teknologi, dan sebagainya.

Pengaruh negatif yang terjadi dapat disaksikan dengan mulai tergesernya bahasa Indonesia karena sebagian besar masyarakat Indonesia lebih mementingkan dan mempelajari bahasa Inggris yang dinilai lebih menjanjikan untuk kedudukan dan taraf ekonomi yang lebih baik. Akibatnya, bahasa Indonesia dapat tergeser oleh bahasa Inggris. Hal ini ditegaskan oleh Mohammad Nuh (2014) bahwa keberadaan Bahasa Indonesia masih terpinggirkan oleh kebijakan, baik segi pendidikan maupun sosial. Sebagai contoh, sebagian besar (hampir semua) perusahaan mengutamakan 
pelamar dapat berbahasa Inggris, tetapi jarang perusahaan yang mengutamakan dapat berbahasa Indoensia. Mengapa hal itu bisa terjadi? Perihal yang harus diingat adalah bahasa memiliki gengsi dan nilai jual. Dalam hal ini, Gunarwan (2000:50) mengatakan bahwa bahasa dapat dilihat sebagai barang manufaktur. Artinya, agar "dibeli" oleh orang (bangsa) lain, bahasa haruslah memiliki keunggulan kompetitif.

Dengan keberadaan bahasa Inggris (bahasa asing) sebagai bahasa internasional, pendidikan Indonesia mulai dari taman bermain sampai dengan perguruan tinggi memiliki kurikulum dan pelajaran bahasa Inggris. Hal ini dilakukan agar sumber daya manusia Indonesia dapat berkiprah dalam era globalisasi. Jika hal ini terjadi, pengaruh bahasa Inggris sangat positif. Namun, pengaruh negatif bahasa asing (Inggris) terhadap bahasa Indonesia sangat besar dan tidak dapat dihindari di era gobal ini. Pengaruh negatif bahasa asing tersebut sudah sangat membahayakan keberadaan bahasa Indonesia. Sering kita menyaksikan, penggunaan kata dan istilah asing digunakan secara bersamaan, berkombinasi, campur aduk dengan bahasa asing, dan sebagainya. Dampak negatif bahasa Inggris terhadap bahasa Indonesia ini tidak akan memerlukan waktu lama untuk menggeser keberadaan bahasa Indonesia.

Perubahan bahasa Indonesia dapat terjadi bukan hanya karena pengembangan dan perluasan, tetapi bisa juga berupa kemunduran selaras dengan perubahan yang terjadi di masyarakat. Berbagai alasan ekonomi, sosial, dan politis menyebabkan banyak orang meninggalkan bahasanya. Dalam perkembangan masyarakat modern saat ini, masyarakat Indonesia cenderung lebih senang, terhormat, dan merasa lebih intelek untuk menggunakan bahasa Inggris. Hal tersebut memberikan dampak terhadap pertumbuhan bahasa Indonesia sebagai jati diri atau identitas bangsa. Bahasa Inggris yang telah menjadi penguasa sebagai bahasa internasional dapat memberi dampak buruk pada perkembangan bahasa Indonesia. Kepopuleran bahasa Inggris menjadikan bahasa Indonesia tergeser posisinya pada tingkat pemakaian di masyarakat.

Berbagai penyebab pergeseran pemakaian bahasa Indonesia tidak hanya disebabkan oleh bahasa asing, tetapi juga disebabkan oleh adanya interferensi bahasa daerah dan pengaruh bahasa gaul. Dewasa ini bahasa asing lebih sering 
digunakan daripada bahasa Indonesia, hampir di semua sektor kehidupan. Dendy (2014) berpendapat, orang Indonesia merasa hebat ketika menggunakan bahasa asing. Banyak kata asing diserap sekadarnya meski sudah ada padanan bahasa Indonesia yang cocok dengan gagasan yang dibicarakan. Sebagai contoh, masyarakat Indonesia lebih sering memberi nama-nama, seperti Garden Hotel, Tunjungan Plaza, International Tailor, Sudirman Cup, Surabaya Shopping Center yang tidak sesuai dengan hukum diterangkan dan menerangkan harus disesuaikan menjadi Hotel Garden, Plaza Tunjungan, Penjahit Internasional, Piala Sudirman, dan Pusat Perbelanjaan Surabaya. Penyesuaian nama ini tidak akan menurunkan harga diri atau derajat perusahaan atau kegiatan tersebut. Sebaliknya, penyesuaian inilah yang disebut penggunaan bahasa Indonesia yang taat asas, baik, dan benar.

Kalau disimak dengan baik, muatan globalisasi sekarang ini meliputi berbagai aspek, seperti politik, ekonomi, budaya, iptek, dan pola hidup bahkan bahasa. Hal ini disebabkan arus komunikasi dan informasi yang begitu dahsyat. Peristiwa ini menuntut negara, dalam hal ini pemerintah sebagai pengambil kebijakan di bidang bahasa, harus hadir untuk 'kerja, kerja, dan kerja' lebih intensif lagi untuk menyempurnakan dan meningkatkan semua sektor yang berhubungan dengan pembinaan dan pengembangan bahasa Indonesia demi mempertahankan dan bahkan mengokohkan keberadaan bahasa sebagai identitas bangsa Indonesia.

Pemerintah saat ini harus bertindak cepat untuk menyelamatkan bahasa Indonesia dari keterpinggiran. Setidaknya, penyelamatan ini dimulai dari pemerintah mengeluarkan undang-undang yang disertai sanksi terhadap pihak-pihak yang tidak mematuhinya. Undang-undang tanpa disertai sanksi hukuman (di Indonesia) sama dengan bohong. Artinya, undang-undang tersebut tidak akan dipatuhi masyarakat sehingga undang-undang kebahasaan adalah kesia-sian. Saat ini yang sangat diperlukan adalah tindakan nyata, bukan hanya sekedar harapan dan himbauan. Selain itu, kebijakan yang mendukung eksistensi bahasa Indonesia sebagai bahasa nasional dan bahasa negara sehingga dapat menjalankan fungsinya, walaupun terdapat sekolah yang dianggap memenuhi standar internasional. Dalam hal ini tidak hanya pemerintah, masyarakat yang berpendidikan harus membantu dan bertanggung jawab sebagai warga negara dalam menyelamatkan bahasa Indonesia 
agar bahasa Indonesia bisa menjadi tuan rumah di negeri sendiri sehingga bangsa Indonesia bisa maju dengan tetap menghargai bahasa negara.

\section{Realitas Kesetiaan Pemakai Bahasa Indonesia}

Sebelum membahas realitas kesetiaan pemakai bahasa Indonesia, alangkah baiknya jika dijelaskan terlebih dahulu tentang arti kesetiaan. Dalam Kamus Besar Bahasa Indonesia (1989:833), kesetiaan adalah keteguhan hati; ketaatan; atau kepatuhan. Berarti, kesetiaan terhadap bahasa Indonesia adalah suatu ketaatan yang menunjukkan rasa suka rela dan bahkan bangga dalam menggunakan bahasa Indonesia sesuai dengan kaidah bahasa sehingga bahasa yang digunakan dapat digolongkan bahasa baik dan benar. Kesetiaan terhadap bahasa Indonesia ini bukan berarti benci terhadap bahasa asing (Inggris). Pemakai bahasa Indonesia yang taat kaidah ini mengetahui kapan dan di mana menggunakan bahasa Indonesia serta kapan dan di mana harus menggunakan bahasa Inggris.

Kesetiaan terhadap bahasa Indonesia adalah suatu sikap patuh yang menunjukkan rasa bangga dalam menggunakan bahasa Indonesia dengan baik dan benar, dibandingkan menggunakan bahasa asing atau kata yang bukan berasal dari bahasa Indonesia, misalnya dalam penggunaan bahasa Indonesia asli atau yang sudah lebih dahulu ada bukan serapan yang berasal dari bahasa asing. Namun, dalam kenyataannya kini masyarakat pada umumnya cendrung lebih banyak memakai serapan bahasa asing dalam beberapa kata bahkan kalimat dibandingkan dengan menggunakan bahasa Indonesia asli dengan baik dan benar.

Pada saat ini, umumnya masyarakat lebih banyak menyukai kata-kata asing (bahasa Inggris) dalam berhasanya daripada berbahasa Indonesia asli dengan baik dan benar. Anehnya, mereka berpendapat bahwa penggunaan bahasa Inggris tersebut supaya lebih mengena ke semua golongan masyarakat dan juga penggunaan bahasa Inggris dianggap lebih kreatif, efektif, dan mudah dipahami. Kesetiaan masyarakat Indonesia terhadap bahasa Indonesia terjadi 'peremehan' (penurunan sikap positif). Dalam hal ini, Chaer (2010:8) menegaskan, bahwa sifat suka meremehkan tampak pada perilaku berbahasa yang "pokoknya mengerti". Penurunan akibat ketidaksetiaan ini dapat ditemukan dalam berbagai macam produk industri, 
nama-nama perusahaan, tema-tema dalam berbagai kegiatan dan sebagainya. Nama produk industri sabun misalnya Lifebuoy, Lux, Dettol, Vaseline, Bee and Flower, Oilum, dan sebagainya. Nama-nama produksi sampo, misalnya Pantene, Sunsilk, Rejoice, Natur, Tresemme, dan sebagainya.

Berdasarkan data-data berbahasa Indonesia di atas, kepatuhan, keteguhan, dan ketaatasasan penggunaan bahasa Indonesia saat ini menunjukkan semakin rendahnya rasa setia masyarakat Indonesia terhadap bahasa bangsanya. Secara tegas dan jelas dicantumkan dalam Undang-Undang Nomor 24 Tahun 2009 Pasal 36 ayat (3) Bahasa Indonesia wajib digunakan untuk nama bangunan atau gedung, jalan, apartemen atau permukiman, perkantoran, kompleks perdagangan, merek dagang, lembaga usaha, lembaga pendidikan, organisasi yang didirikan atau dimiliki oleh warga negara Indonesia atau badan hukum Indonesia.

Akibat rendahnya kesetiaan pemakai bahasa yang tidak setia terhadap bahasa milik sendiri membuktikan bahwa mulai lenyapnya bahasa Indonesia. Pada akhirnya, bangsa Indonesia akan dapat kehilangan bahasa Indonesia yang berarti pula bangsa Indonesia tercerabut budaya dan jati dirinya. Bangsa Indonesia harus menyadari bahwa bahasa Indonesia dalam konteks kebudayaan nasional merupakan komponen yang paling representatif dan dominan, termasuk upaya melanggengkan kesatuan bangsa (Hasan Alwi, 1998).

\section{Simpulan dan Saran}

Kesetiaan berbahasa Indonesia merupakan suatu sikap patuh, taat, dan bangga menggu-nakan bahasa Indonesia dibandingkan menggunakan bahasa yang bukan berasal dari bahasa Indonesia. Namun, berbagai kesalahan berbahasa Indonesia sering dilakukan oleh pemakai bahasa, baik secara lisan maupun secara tulis; baik oleh kaum awam, terpelajar maupun kalangan artis, dan pejabat. Di antara berbagai kesalahan tersebut adalah kesalahan penulisan dan pelafalan fonem dan kesalahan fonetis. Kesalahan ini terus saja terjadi padahal kesalahan tersebut sangat memungkinkan terjadinya salah penafsiran dan bahkan mengakibatkan kesalahan informasi. 
Bangsa Indonesia, sebagai pemakai sekaligus pemilik bahasa Indonesia, seharusnya bisa menghindari kesalahan berbahasa dan seharusnya setia menggunakan bahasa Indonesia yang baik dan benar sebagai alat komunikasi. Kesetiaan berbahasa Indonesia merupakan keharusan sebagai masyarakat bangsa yang memiliki jati diri. Hal ini juga telah ditegaskan pada Undang-Undang Nomor 24 Tahun 2009, yakni Pasal 36 ayat (3) Bahasa Indonesia wajib digunakan untuk nama bangunan atau gedung, jalan, apartemen atau permukiman, perkantoran, kompleks per-dagangan, merek dagang, lembaga usaha, lembaga pendidikan, organisasi yang didirikan atau dimiliki oleh warga negara Indonesia atau badan hukum Indonesia. Namun, berbagai kenyataan yang terjadi, tidaklah demikian.

Penghargaan dan gengsi terhadap bahasa asing (bahasa Inggris) masih terus menguat pada sebagian besar bangsa Indonesia. Pada umumnya, masyarakat menganggap bahwa bahasa asing lebih tinggi derajatnya daripada bahasa Indonesia. Bahkan, kita seolah tidak mau tahu kedudukan, fungsi, dan perkembangan bahasa Indonesia. Anggapan semacam itulah yang harus diluruskan. Sebab, jika tidak diluruskan akan berakibat punahnya jati diri dan identitas bangsa, yakni bahasa Indonesia.

Ketidaksetiaan berbahasa Indonesia jika tidak diperbaiki akan berakibat perkembangan bahasa Indonesia terhambat. Oleh sebab itu, sebagai warga negara Indonesia yang baik, sepantasnyalah bahasa Indonesia itu dicintai. Bahasa Indonesia harus dibina dan dikembangkan dengan baik karena bahasa Indonesia itu merupakan salah satu identitas atau jati diri bangsa Indonesia. Setiap orang Indonesia patutlah bersikap positif terhadap bahasa Indonesia, janganlah menganggap remeh dan bersikap negatif. Setiap orang Indonesia mestilah berusaha agar selalu cermat dan teratur menggunakan bahasa Indonesia. Sebagai warga negara Indonesia yang baik, mestilah dikembangkan budaya malu apabila meraka tidak mempergunakan bahasa Indonesia dengan baik dan benar.

Setiap warga negara Indonesia harus bersama-sama berpartisipasi dalam membina dan mengembangkan bahasa Indonesia itu ke arah yang positif dan lebih baik. Usaha-usaha ini, antara lain dengan meningkatkan kedisiplinan berbahasa Indonesia pada era global ini karena sangat ketat dalam persaingan di 
segala sektor kehidupan. Maju bahasa, majulah bangsa. Kacau bahasa, kacaulah pulalah bangsa. Keadaan ini harus disadari benar oleh setiap warga negara Indonesia sehingga rasa tanggung jawab terhadap pembinaan dan pengembangan bahasa Indonesia akan tumbuh dengan subur di sanubari setiap pemakai bahasa Indonesia. Rasa cinta terhadap bahasa Indonesia pun akan bertambah besar dan bertambah mendalam. Sudah barang tentu, hal ini merupakan harapan bersama, harapan setiap orang yang mengaku berbangsa Indonesia. Kesetiaan bahasa mendorong masyarakat suatu bahasa mempertahankan bahasanya dan apabila perlu mencegah adanya pengaruh bahasa lain. 


\section{DAFTAR PUSTAKA}

Alwi, Hasan, dkk. 2000. Bahasa Indonesia dalam Era Globalisasi: Pemantapan Peran Bahasa sebagai Sarana Pembangunan Bangsa. Jakarta: Pusat Pembinaan dan Pengembangan Bahasa Departemen Pendidikan Nasional.

Alwi, Hasan, dkk. 2000. Tata Bahasa Baku Bahasa Indonesia. Jakarta: Balai Pustaka.

Chaer, Abdul dan Leoni Agustina. 1995. Sosiolinguistik Perkenalan AwalJakarta: Rineka Cipta. Diunduh 20 Agustus 2015.

Chaer, Abdul. 2010. Kesantunan Berbahasa Indonesia. Jakarta: Rineka Cipta.

http://suaramerdeka.com/v1/index.php/read/cetak/2014/08/26/271454/BahasaIndonesia-Masih-Terpinggirkan. Diunduh 21 Agustus 2015.

http://radiobuku.com/2014/09/bahasa-indonesia-terpinggirkan-di-pusatperbelanjaan. Diunduh 24 Agustus 2015.

Pusat Pembinaan dan Pengemangan Bahasa. 1989. Kamus Besar Bahasa Indonesia. Jakarta: Balai Pustaka.

Setyawati. 2010. Analisis Kesalahan Berbahasa Indonesia. Surakarta: Yuma Pustaka. 